\title{
Meme: gênero e prática de ensino pela sequência
} didática

\author{
Meme: género y práctica de enseñanza por medio de una
} secuencia didáctica

Meme: genre and teaching through didactic sequence

\author{
Ulisses Oliveira ${ }^{1}$
}

\begin{abstract}
RESUMO: O presente artigo tem o objetivo de discutir o ensino do gênero meme nos termos de aplicação da sequência didática como proposta pedagógica interventiva em turmas de EJA (nono ano), numa escola pública no Estado de São Paulo. O artigo, com base nesse estudo de caso, discute aspectos do referido gênero pela perspectiva teórica da Estrutura Potencial Genérica e da Gramática do Design Visual. No interior da proposta, caracterizamos o meme como um gênero emergente e de grande interesse dos alunos, os quais, no decorrer da pesquisa, puderam desenvolver competências de leitura e produção de memes, fazendo uso mais consciente dos elementos visuais e textuais característicos do gênero. Além disso, a intervenção pedagógica foi efetiva no sentido de explorar questões vinculantes de letramento crítico e multiletramentos na reconstrução de paradigmas, valores e ideologias adstritos ao desenvolvimento da competência comunicativa multimodal no gênero.
\end{abstract}

PALAVRAS-CHAVE: Letramento crítico. Gramática do Design Visual. Gênero. Meme.

RESUMEN: El presente artículo tiene el objetivo de discutir la enseñanza del género meme en los términos de aplicación de la secuencia didáctica como propuesta pedagógica intervencionista en las clases de EJA (noveno año), en una escuela pública en el Estado de São Paulo. El artículo, con base en ese estudio de caso, discute aspectos de dicho género por la perspectiva teórica de la Estructura Potencial Genérica y de la Gramática del Diseño Visual. En el interior de la propuesta, caracterizamos al meme como un género emergente y de gran interés de los alumnos, los cuales, en el transcurso de la investigación, pudieron desarrollar competencias de lectura y producción de memorias, haciendo uso más consciente de los elementos visuales y textuales característicos del género. Además, la intervención pedagógica fue efectiva en el sentido de explorar cuestiones vinculantes de

\footnotetext{
${ }^{1}$ Doutor em Linguística Aplicada e Estudos da Linguagem pela Pontifícia Universidade Católica (PUCSao Paulo) e possui Mestrado na mesma área pela mesma universidade. Atualmente, atua como professor na Universidade Federal de Mato Grosso do Sul (UFMS). E-mail: ulisvaz@gmail.com.
} 
Meme: gênero e prática de ensino pela sequência didática

letra crítico y multiletramentos en la reconstrucción de paradigmas, valores e ideologías adscritas al desarrollo de la competencia comunicativa multimodal en el género.

PALABRAS CLAVE: Letramento crítico. Gramática del diseño visual. Género. Meme.

\begin{abstract}
This paper aims to present a research of teaching memes, in terms of the application of the didactic sequence as an interventive pedagogical proposal in classes of adult education (highschool final years), in a public school in the State of São Paulo. The paper, based on this case study, discusses aspects of this genre through the theoretical perspective of the Generic Potential Structure and the Visual Design Grammar. Within the proposal, we characterized the meme as an emergent genre of great interest of students, who, during the research, could develop reading and writing skills of memes, having a more conscious use of visual and textual elements which are aspects thereof. In addition, the pedagogical intervention was effective in exploring linking matters related to critical literacy for the reconstruction of paradigms, values and ideologies attached to the development of the multimodal communicative competence in the genre.
\end{abstract}

KEYWORDS: Critical Literacy. Visual Design Grammar. Genre. Meme.

\title{
1 Introdução
}

Os Parâmetros Curriculares Nacionais (BRASIL, 1998) propõem que as aulas de Língua Portuguesa devem ser planejadas a partir de um olhar mais detalhado sobre determinados gêneros. Tal olhar mais qualificado possibilita ao aluno as condições necessárias para desenvolver competências de leitura e escrita diversificadas, além daquelas que ele já possui. Portanto, o domínio de diferentes gêneros pode levar o aluno a ocupar, com maior consciência, diferentes esferas sociais onde pode falar, escrever e agir com a linguagem de forma mais eficaz. Além disso, o ensino de gêneros textuais contemporâneos, além de motivar o aluno, atende à crescente exigência de letramento crítico no Brasil.

Raramente se observa, na prática de sala de aula, a concepção de leitura enquanto processo interativo (leitor-texto-autor), a partir da recuperação explícita do que se acredita serem as marcas deixadas pelo autor, únicas responsáveis pelos sentidos possíveis. Mais raramente ainda, para não dizer nunca $[. .$.$] , a concepção discursiva$ se vê contemplada: raramente são permitidas, em aula, outras leituras que não sejam a do professor (CORACINI, 1995). 
A partir da leitura crítica, a escola deve auxiliar o discente a desenvolver a leitura e a escrita (MATTOS; VALÉRIO, 2010). Sendo assim, a proposta do presente trabalho se justifica pela utilização de um gênero altamente crítico, o meme. Ademais, é um gênero aceito pelos jovens e, por estar em um alcance maior do contexto social e comunicativo dos alunos, é possível que também propicie boas condições para o desenvolvimento da escrita persuasiva de nossos alunos. Por se tratar de texto multimodal, o meme revela dimensões de contexto através da linguagem verbal e não verbal, utilizando imagens icônicas que já trazem consigo uma mensagem, geralmente crítica, subjacente ao texto.

$O$ objetivo do presente artigo é discutir o ensino do gênero meme nos termos de aplicação da sequência didática como proposta pedagógica interventiva em turmas de EJA (nono ano), numa escola pública no Estado de São Paulo. Os textos trabalhados em sala de aula e a produção dos alunos foram analisadas com base nos pressupostos teóricos da Estrutura Potencial Genérica e da Gramática do Design Visual, pois as mesmas fornecem um arcabouço teórico, como veremos adiante, que permite ao professor desenvolver junto aos seus alunos traços distintivos do gênero. A sequência didática se insere como uma ferramenta teórico-metodológica de caráter educacional para que professor e alunos consigam identificar as funções e empregar com adequação ao gênero.

\section{Meme}

O meme é considerado "uma unidade mínima de informação que se multiplica de cérebro em cérebro, ou entre locais onde a informação é armazenada" (BLACKMORE, 2000). Numa perspectiva mais abrangente, podem ser ideias ou partes de ideias, línguas, sons, desenhos, capacidades, valores estéticos e morais, ou qualquer outra coisa que possa ser aprendida facilmente e transmitida como 
Meme: gênero e prática de ensino pela sequência didática

unidade autônoma (DAWKINS, 1976). Graças a world wide web, os memes vêm cada vez mais atingindo milhares de pessoas em alguns instantes, principalmente por investir em linguagem informal a partir de imagens icônicas.

Davison (2012) considera que os memes carregam em si uma bagagem histórica, social e política; e seria impossível desconsiderar a existência da linguagem persuasiva e ideológica em tais gêneros textuais. Alguns memes satirizam aspectos econômicos e políticos do país e questionam valores e paradigmas sociais e culturais. O autor considera que as escolhas linguísticas realizadas na construção desses textos revelam crenças, valores e concepções sobre o mundo, ou seja, refletem a ideologia, a cultura e o significado valorativo na construção de uma identidade cultural. Nesse sentido, o desenvolvimento das competências de leitura e produção textual de memes deve também considerar a representação, criação e/ou reconstrução de paradigmas, valores e ideologias contidos nos textos e construídos a partir deles.

Do ponto de vista da construção composicional do meme, igualmente importante para a delineação do gênero conforme o círculo de estudos bakhtinianos, a presente pesquisa enfocará a questão quando da análise da produção discente pela interface com a Estrutura Potencial Genérica, teoria que abordaremos mais adiante.

Devido à crescente popularidade da internet entre os jovens, os memes tornam-se, cada vez mais, um gênero popular nas salas de aula, principalmente por: (a) tratar de temas da maior variedade de interesses; (b) investir em linguagem informal, algumas vezes vulgar; (c) fazer uso de imagens icônicas; e (d) ter alta capacidade de difusão. De acordo com Maciel e Takaki (2015), há relevância em se empregar os memes com fins pedagógicos.

[os memes] são entendidos como artefatos sociolinguísticos-culturais online, os quais podem ser copiados, reeditados e disseminados com propósitos sociais definidos, partindo de suas concepções e características para então, lançar sinais de possibilidades de seu uso nas salas de aula (MACIEL; TAKAKI, 2015, p. 54) 


\section{Meme: gênero e prática de ensino pela sequência didática}

Além disso, o trabalho com os memes em sala de aula são uma oportunidade para aprimorar a leitura de contexto, a leitura inferencial, a multimodalidade, tropos como a ironia, a metáfora e a metonímia e, principalmente, a prática do letramento crítico e multiletramentos, como enfoca a presente pesquisa, na tradição de estudos análogos recentes (e.g. MAGNANI, 2011; MASSARUTO; DO VALE; ALAIMO, 2017; MENDONÇA; LARA, 2017; OLIVEIRA; MALTA; AQUINO, 2017).

\section{Letramento Crítico e Multiletramentos}

Segundo Possenti (1998), é papel da escola incentivar os alunos a lerem e escreverem, na própria sala de aula, textos relacionados com política, economia, educação, etc. Tal prática ajudaria os alunos a se prepararem melhor para a vida adulta, pois assim poderiam ter um entendimento mais crítico do mundo que os cerca. No entanto, alguns autores argumentam (e.g. MATTOS; VALÉRIO, 2010) que apenas recentemente, com a redemocratização do ensino, que a questão do letramento crítico ganhou destaque nas escolas, uma vez que sua "acepção [...] situa a produção de significação sempre em termos do pertencimento sócio-histórico dos produtores de significação, e postula tanto leitores quanto autores como igualmente produtores de significação" (MINAYO, 2011, p. 4).

A teoria da crítica social defendida por Cervetti, Pardales e Damico (2001) afirma que a existência está associada à ideia de que através da linguagem, podemos atuar nas diferentes práticas sociais, de modo a nos posicionar enquanto sujeitos críticos e provocar mudanças se assim desejarmos. Para Garcia (1988, p. 55) seguindo os estudos de Marx, "a ideologia passa a ser o sistema das idéias, das representações que domina o espírito de um homem ou um grupo social", portanto, seria "impossível compreender a origem e função da ideologia sem compreender a luta de classes, pois a ideologia é um dos instrumentos da dominação de classe e uma das formas da luta de classes". Daí porque propostas de ensino de letramento crítico compreendem que um dado texto é um produto de forças ideológicas e 
sociopolíticas, um local de luta, de negociação e de mudanças. Partindo dessa perspectiva, propusemos a análise dos memes de maneira crítica, verificando as opiniões, ideologias e interesses presentes nesse gênero que, constantemente, apresenta representações de estereótipos e caricaturas para condensar significados ideológicos subjacentes ao texto.

Além disso, o meme tem a particularidade de ser um gênero multimodal, o que nos leva a discutir multiletramentos. 0 meme emprega uma multiplicidade de linguagens, mídias e tecnologias. Portanto, ao traballhar com o gênero em sala de aula, professores e alunos também precisam dominar áudio, vídeo, tratamento de imagem, edição e diagramação, entre outras. Para Rojo e Moura (2012, p. 21), "são requeridas novas práticas de leitura, escrita e análise crítica, em suma, novos multiletramentos".

Os multiletramentos funcionam, pautando-se em algumas características importantes: (a) são interativos; (b) rompem as relações de poder estabelecidas; e (c) são híbridos, fronteiriços, mestiços (de linguagens, modos, mídias e culturas) (ROJO; MOURA, 2012, p. 23). Tais características impõem um novo modo de conceber, por exemplo, a autoria e a recepção dos enunciados. Ou seja,

[...] o processo de produção textual não é mais exclusivamente linguístico, integra imagem, som, movimento; além disso, não se vivencia mais uma produção estritamente individual ou de mão única (aluno-professor), mas colaborativa - mais de um sujeito contribui para a produção e retextualização" (KARWOSKI; GAYDECZKA, 2013, p. 5).

Assim, objetos discursivos como os memes, (i. e. hipermodais polifônicos) desafiam profissionais da educação a rever a produção, leitura e ensino de enunciados. Para Coscarelli e Ribeiro (2007, p. 29), "cabe, então, a nós professores, sobretudo das classes populares, criarmos formas de incluir nossos alunos nessa viagem, e para isso, devemos dar a eles os equipamentos necessários para serem bem-sucedidos nessa empreitada". 
Meme: gênero e prática de ensino pela sequência didática

\section{Gramática do Visual e o Texto Multimodal}

O texto visual é tão complexo quanto o texto verbal, devido a sua estrutura e funções específicas. Nesse contexto, como dito anteriormente, novos gêneros midiáticos como o meme destacam a importância da compreensão do texto visual juntamente com o verbal. Kress e Van Leeuwen (1996) propõem uma leitura da Gramática do Design Visual (doravante GDV) num esforço de didatização do texto multimodal, o qual, como dissemos, realiza-se por mais de um código semiótico, por exemplo, palavras e imagens combinadas. Os autores falam sobre a necessidade de uma análise que leve em conta também elementos não verbais, pois mostram que, cada vez mais, a monomodalidade dá lugar à multimodalidade em todos os setores de comunicação.

Os textos multimodais estão estritamente ligados com 0 universo sociocultural, pois a linguagem visual abrange diferentes códigos sígnicos relacionados a variados contextos. Dessa forma, não só devemos considerar uma prática pedagógica com foco na formação do leitor capaz de interpretar a linguagem visual e que reconheça um processo para fazê-lo, mas também reconhecermos a multimodalidade como um novo conceito de letramento (KREES; VAN LEEUWEN, 1996). Para Kress e Van Leeuwen (2001), a GDV entende que a produção de signos está relacionada com os meios formais de comunicação e representação existentes na sociedade e, portanto, considera que as formas de significação são afetadas pela estrutura social, política, econômica e ideológica que modelam o contexto de produção dos textos.

Algumas particularidades do texto multimodal vêm sendo investigados no seio da GDV. Por exemplo, de acordo com Kress e Van Leeuwen (1996, p. 187), o lado esquerdo da página de um texto multimodal traz geralmente as informações já conhecidas ou pressupostas, que são denominadas de elemento Dado, já o lado direito é considerado de maior evidência, apresentando o elemento Novo. A Saliência 
é o fator que atrai o olhar das pessoas para um ponto específico da imagem. Os elementos mais salientes destacam-se geralmente por fatores como: tipo de imagem, tamanho, cores ou perspectiva. Além disso, quando o elemento está posicionado no centro da página, é denominado elemento Central, enquanto que, nas margens, o elemento é Marginal. Segundo a teoria, o posicionamento da imagem nos eixos superior e inferior da página também produz significados, discriminados pelos autores como Ideal e Real. No eixo superior, as informações são normalmente generalizadas, denominadas de Ideal; já no eixo inferior, está o item informativo mais específico, denominado Real.

Um aspecto fundamental a ser considerado na multimodalidade são as cores. Muitos pesquisadores corroboram a importância do conhecimento do aparelho ótico humano e do cérebro com suas capacidades cognitivas (DONDIS; CAMARGO, 1997). A cor revela informações culturais, como costumes, crenças, religião, simbolismo histórico, mitos, etc. O conhecimento sobre as cores demonstra, além dos significados culturais, a influência que elas exercem sobre o indivíduo. Dondis e Camargo (1997, p. 64-65) caracteriza isso como "significados associativos e simbólicos". Por exemplo, segundo a autora, o vermelho está culturalmente associado a sentimentos fortes, como perigo, amor, calor e vida; o amarelo tende a ser relacionado com expansão; e o azul é considerado suave, calmante e passivo.

Além das cores, a distância social² e a perspectiva agregam significados igualmente relevantes na leitura da imagem. Com base na GDV, o que determina a distância social é proximidade do participante representado em relação ao ponto de vista do leitor. Essa distância pode ser íntima (distância de proximidade), pessoal (distância média) ou social (distância longa). Também relacionada à distância, a perspectiva da imagem diz respeito ao ângulo pelo qual o participante é mostrado,

\footnotetext{
${ }^{2}$ A esse respeito, distância social, o fenômeno foi inicialmente estudado por Ervin Goffman (1967) e por Penelope Brown e Stephen Levinson pela Teoria da Polidez (BROWN; LEVINSON, 1987), principalmente no desenvolvimento do conceito de face, porém não iremos examiná-lo neste artigo.
} 
Meme: gênero e prática de ensino pela sequência didática

podendo ser frontal, oblíquo ou vertical. No texto multimodal, tais elementos são constitutivos do gênero, como trataremos adiante.

\section{A Teoria de Gênero e Registro e a Estrutura Potencial Genérica}

A Teoria de Gênero e Registro (doravante TGR) (EGGINS; MARTIN, 1997) postula que a relação entre linguagem e gênero é fundamental para o entendimento das escolhas linguísticas potenciais, contexto cultural, situacional e interação social. Segundo a TGR, diferentes contextos produzem textos distintos, ou seja, a decodificação depende da associação de traços linguísticos em contexto, o qual engloba a ideologia como camada contextual de ordem superior, o contexto de cultura, também denominado Gênero ${ }^{3}$, e o contexto situacional imediato, ou Registro (EGGINS; MARTIN, 1997). Para Halliday e Hasan (1989), os elementos do contexto situacional que influem no uso da língua são: (a) Campo (o assunto sobre o que a língua está sendo usada); (b) Relação (a interação entre os interlocutores); e (c) Modo (o papel que a língua exerce na informação e na interação). A TGR investiga o modo como as diferenças de contexto constroem textos distintos. Padrões linguísticos configuram-se nos textos através de um conjunto específico de valores que realizam o Campo, as Relações e o Modo do discurso (HALLIDAY; HASAN, 1989, p. 55), denominado "configuração contextual".

No escopo dos estudos sobre gênero, a Estrutura Potencial Genérica (EPG) surge como um modelo analítico que considera que a estrutura textual de um dado gênero pode variar, mas dentro das fronteiras delimitadas pela relação dos elementos textuais que orientam a sua caracterização (HASAN, 1989). A EPG considera estágios potenciais dos gêneros, podendo ser eles: obrigatórios (componentes essenciais), opcionais (são variáveis e não representam prejuízos à

\footnotetext{
${ }^{3}$ Grafado com inicial maiúscula referindo-se ao conceito cunhado por Halliday (1994), o qual descreve a influência das dimensões do contexto cultural sobre a língua.
} 
compreensão do gênero) e iterativos (recursivos no texto), conforme a funcionalidade por eles desempenhada na estrutura textual. A escolha desses elementos para compor a estrutura textual é análoga às escolhas realizadas no sistema da língua: sofrem influências contextuais. Uma vez que as pesquisas sobre memes não revelaram ainda todos os aspectos constitutivos do gênero, a EPG fornece ferramentas metodológicas importantes para a identificação de estágios e finalidades no gênero. Notamos, portanto, que a EPG endereça especialmente a construção composicional do meme ao examinar os "modos típicos de organização do texto quanto a que partes o compõem e como elas se distribuem". (COSTA VAL, 2003, p. 126).

\section{Sequência Didática}

Para sistematizar o progresso do ensino de gêneros textuais na escola, fazse necessário uma prática que proporcione uma progressão contínua para a aprendizagem dos mais variados gêneros. Nesse tocante, a sequência didática (doravante SD) é uma proposta teórico-pedagógica a qual cumpre tal sistematização analítica com viés pedagógico.

Desenvolvida e consolidada por Dolz, Noverraz e Schneuwly (2004) e colaboradores, a SD oferece uma proposta de ensino gradual oportuna para a aprendizagem de gêneros, ao passo que permite ao discente adequar sua linguagem numa situação comunicativa encaixada. Segundo os autores, a sequência didática é constituída por quatro etapas: apresentação da situação; produção inicial; módulos e produção final.

A respeito da SD, a primeira etapa é subdividida em duas dimensões: projeto coletivo de produção de um gênero oral ou escrito e dimensão dos conteúdos. Aquela refere-se à definição da produção, ou seja, dos interlocutores, do gênero, e da sua forma. A dimensão dos conteúdos se constitui na discussão do tema e na 
exposição de textos do mesmo gênero produzido. A produção inicial é constituída pela primeira produção do aluno do gênero solicitado. Assim, haverá um diagnóstico do conhecimento prévio do alunado, ou seja, a percepção do conhecimento dos alunos. A terceira etapa - "módulos" - é pautada na superação das dificuldades diagnosticadas na produção inicial. Tendo uma estrutura maleável, pois será desenvolvida com relação às necessidades dos alunos. A última etapa, produção final, é um instrumento de avaliação da curva de aprendizagem dos alunos desde a primeira produção, ou seja, é a possibilidade de efetivar os aprendizados dos módulos e verificar sua eficiência no processo de ensino-aprendizagem do gênero em questão.

A seguir, trataremos dos procedimentos metodológicos adotados na pesquisa.

\section{Metodologia}

Os textos foram produzidos entre os meses de março e junho de 2017 em sala de aula por 24 alunos da Educação de Jovens e Adultos do nono ano da Escola Estadual Lydia Helena Frandsen Stuhr de Birigui-SP. Dentre os critérios de produção do gênero textual (meme) e temática, a orientação basilar foi a predileção de texto ideologicamente denso, polêmico e de indelével força persuasiva. Para escrevê-los, os alunos utilizaram aplicativos de produção de memes, os quais trazem um banco de dados substancial de imagens icônicas ${ }^{4}$.

Com respeito aos procedimentos adotados, foram: (a) apresentação da situação e produção inicial, com a exposição do projeto coletivo da turma a partir da apresentação de um meme sobre futebol. 0 professor deu indicações sobre o que os alunos deveriam produzir, quem seriam os destinatários, as finalidades, o gênero a ser abordado, o suporte material da produção. Dentre um rol de possíveis temas, os alunos escolheram "machismo e feminismo"; (b) realização dos módulos

\footnotetext{
${ }^{4}$ Alguns desses aplicativos são meme generator, meme creator, GATM meme, memegene, etc.
} 
de intervenção pedagógica, seguidos das etapas de refacção textual; e (c) análise dos memes produzidos, com enfoque na Estrutura Potencial Genérica (EPG) do gênero, buscando estabelecer hipóteses de estágios obrigatórios, opcionais e iterativos nos memes pela perspectiva do texto multimodal (cf. GDV).

\section{Aplicação da Sequência Didática}

A produção inicial (doravante PI) revelou aspectos interessantes para a orientação dos módulos. Elencamos, adiante, aqueles mais marcantes:

(a) inadequação ao gênero - por vezes (35\% da amostra), os alunos criaram textos que não atendiam aos cânones do gênero adotado, como, por exemplo, a elaboração de textos com estrutura análoga à tira humorística, entre outros; (b) paradigmas ideológicos cristalizados - cerca de $70 \%$ dos textos revelaram complexos ideológicos cristalizados, geralmente associados a estereótipos; (c) dificuldade em articular humor e crítica social com adequação - algumas representações foram ofensivas na consideração de valores éticos e intersubjetividade, segundo relato do próprio grupo analisado; e (d) ineficiência no uso de recursos persuasivos - embora tenham apresentado leitura bastante crítica, alguns alunos ( $17 \%$ da amostra) empregaram poucos ou nenhum recurso persuasivo, principalmente aqueles de ordem implícita, para construir os significados pretendidos. As Figuras 1 e 2, a seguir, exemplificam as dificuldades supracitadas. 
Meme: gênero e prática de ensino pela sequência didática

Figura 1 - Exemplo de Produção Inicial: inadequação ao gênero e dificuldade em articular humor e crítica social com adequação

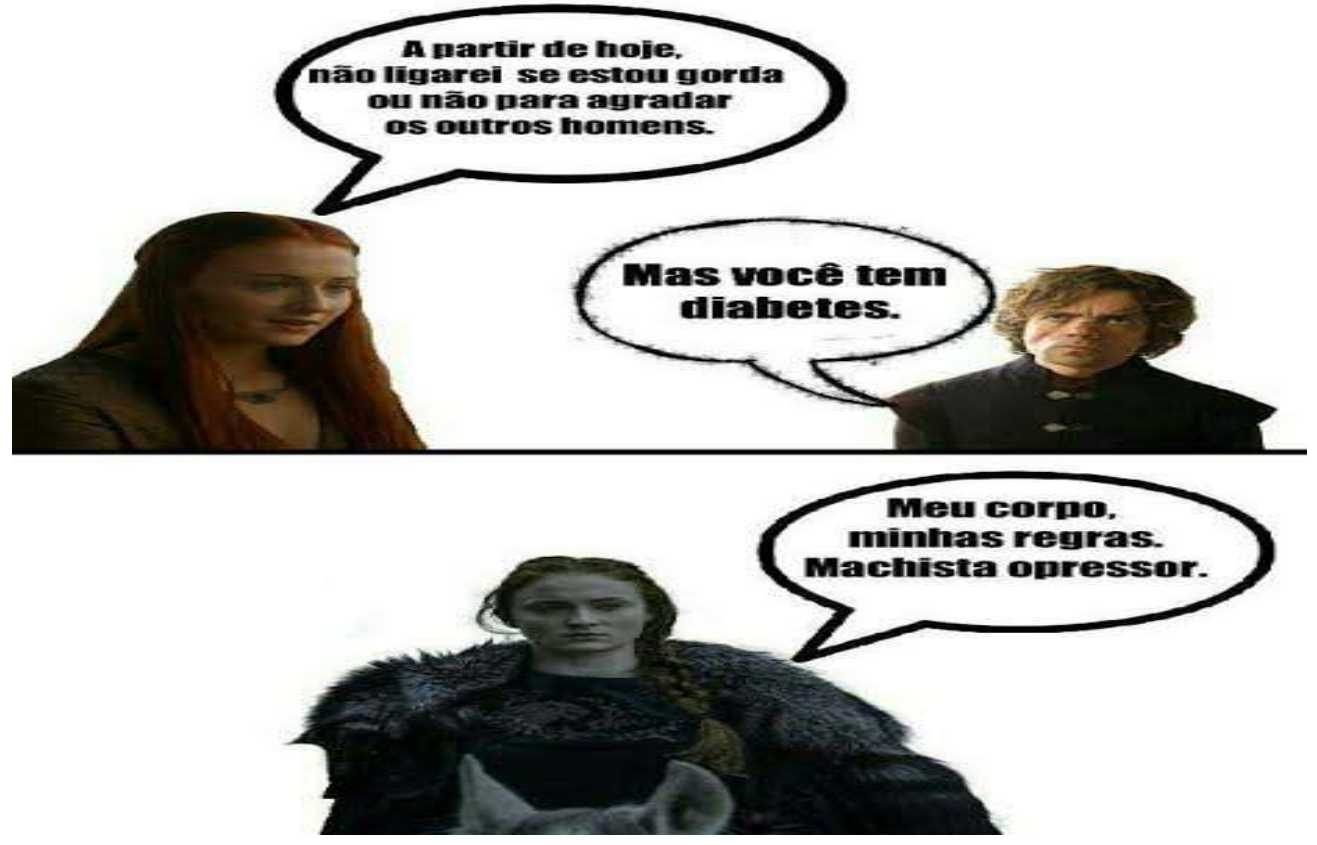

Fonte: Autor

Figura 2 - Exemplo de Produção Inicial: paradigmas ideológicos cristalizados e ineficiência no uso de recursos persuasivos

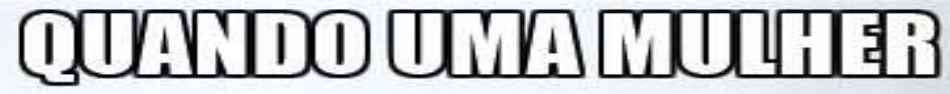

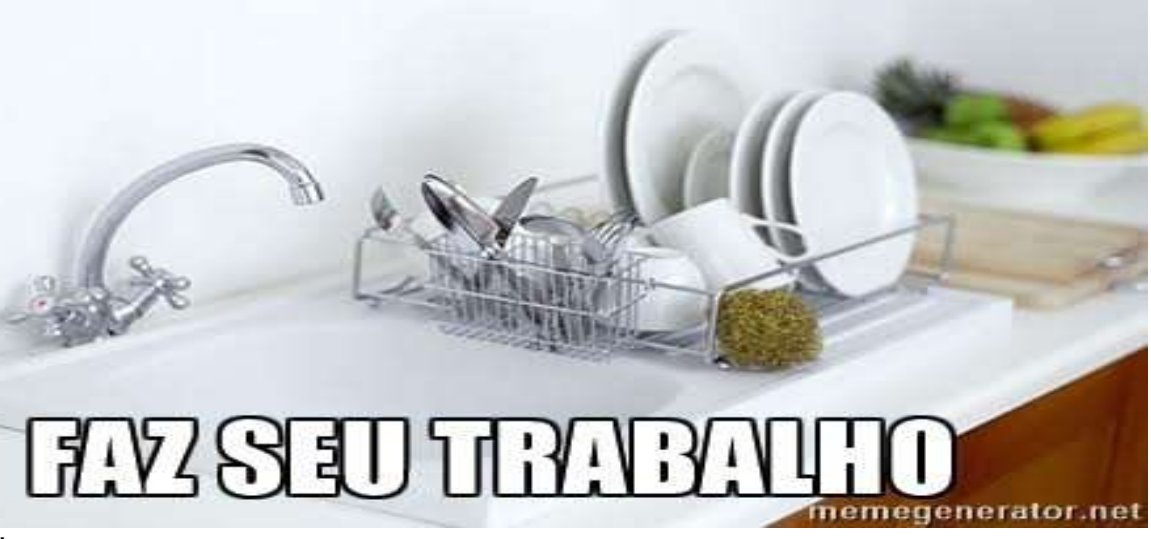

Fonte: Autor

A partir da análise da PI, nas aulas seguintes, ocorreram as etapas de intervenção modular conforme a SD. Foram ministradas 08 aulas de 50 minutos, 
divididas igualmente em quatro módulos (a), (b), (c), e (d) - detalhados a seguir com o endereçamento das seguintes questões:

(a) estágios e finalidades do meme - enfoque na imagem e sua relação com o texto escrito, os objetivos discursivos do meme, os interlocutores, a ofensa (falta de empatia, depreciação e injúria) e as possibilidades de construir convencimento (persuasão) a partir de opinião crítica não abertamente ofensiva. Foram feitas interferências e apresentados exemplos de textos, de modo que os alunos percebessem a presença da avaliatividade ${ }^{5}$, letramento crítico, conceito de face ${ }^{6}$, recursos persuasivos - principalmente implícitos - e a combinação de elementos dos textos multimodais característicos do gênero escolhido. É importante mencionar que não foram trabalhados termos técnicos e conceituações complexas com os alunos, uma vez que a teoria é bastante.

(b) organização do texto multimodal, com vistas a discutir pressupostos fornecidos pela GDV, enfatizando imagens, cores, posicionamento (texto e imagem) e outras características. $O$ objetivo foi mostrar como estratégias do texto multimodal poderiam ser empregadas em memes, conforme as Figuras 3, 4, 5 e 6, a seguir.

\footnotetext{
${ }^{5}$ A avaliatividade (MARTIN, 2000) examina a semântica da avaliação na construção de significado interpessoal, abrangendo envolvimento e negociação.

${ }^{6} \mathrm{O}$ conceito de face (GOFFMAN, 1976) refere-se aos valores pessoais, ligados ao self, em jogo durante a interação comunicativa.
} 
Figura 3-GDV: Dado e Novo

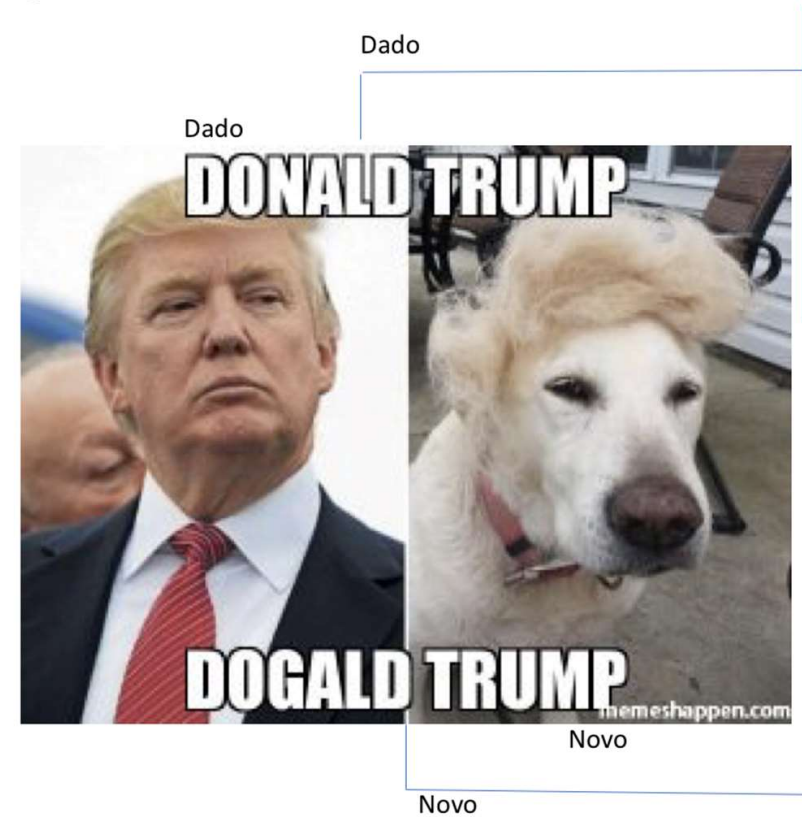

O lado esquerdo da página de um texto multimodal traz geralmente as informações já conhecidas ou pressupostas, que são denominadas de elemento Dado, já o lado direito é considerado de maior evidência, apresentando o elemento Novo (cf. GV). No caso do meme, a tendência é de que o Dado no texto verbal esteja no quadrante superior, enquanto o Novo no infeior.

Fonte: Autor

Figura 4 - GDV: Saliência e Marginal

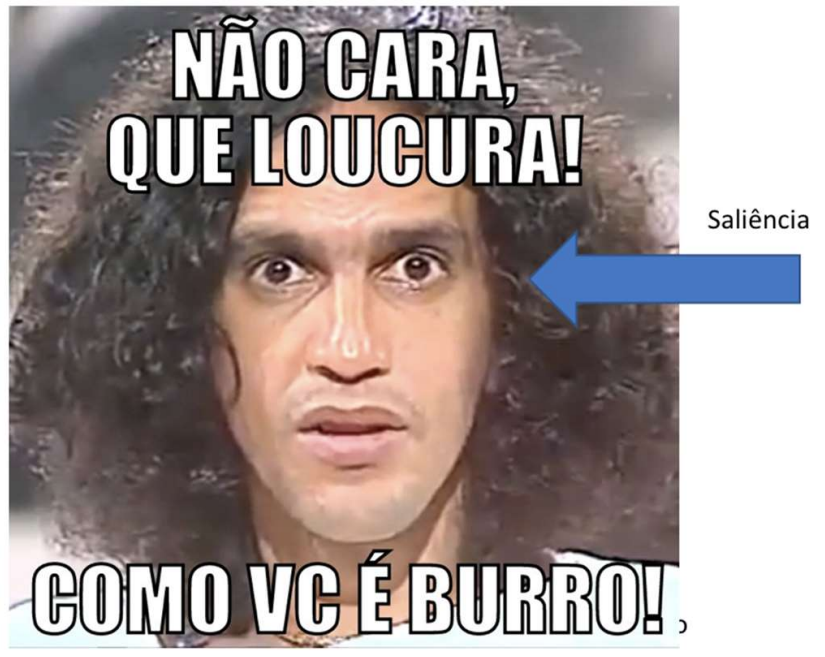

A Saliência é o fator que atrai o olhar das pessoas para um ponto específico da imagem. Os elementos mais salientes destacam-se geralmente por fatores como: tipo de imagem, tamanho, cores ou perspectiva. Além disso, quando o elemento está posicionado no centro da página, é denominado elemento Central, enquanto que, nas margens, o elemento é Marginal. No caso do meme, na maior parte das vezes, a Saliência é fornecido pela própria imagem, enquanto o enunciado verbal é Marginal ou complementar.

Fonte: Autor 
Figura 5-GDV: Ideal e Real

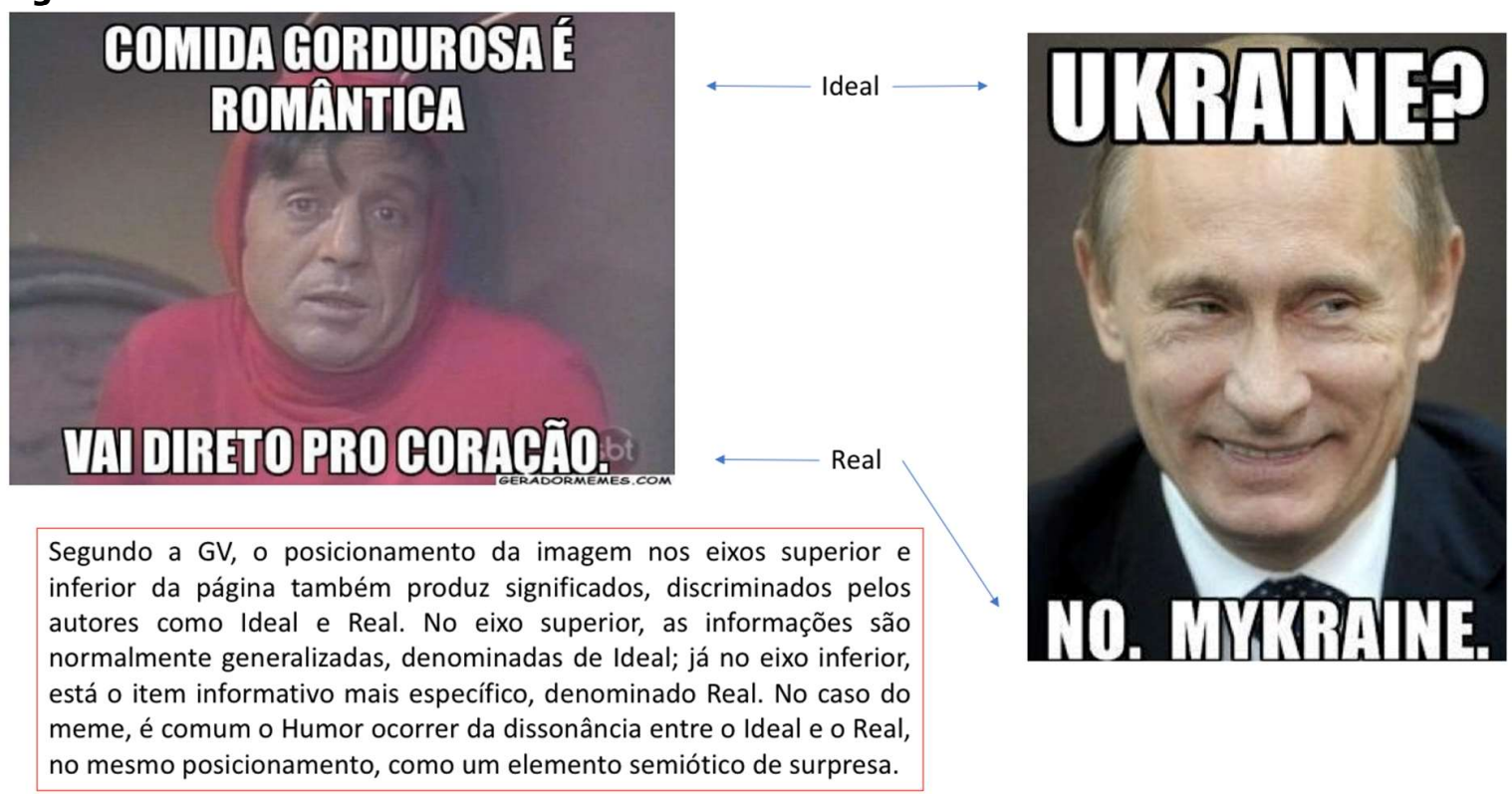

Fonte: Autor

Figura 6-GDV: Ideal e Real

Segundo a GV, a distância social e a perspectiva agregam significados igualmente relevantes. Com base nessa teoria, o
que determina a distância social é proximidade do participante representado em relação ao ponto de vista do leitor.
Essa distância pode ser íntima (distância de proximidade), pessoal (distância média) ou social (distância longa). Também
relacionada à distância, a perspectiva da imagem diz respeito ao ângulo pelo qual o participante é mostrado, podendo
ser frontal, obliquo ou vertical. Percebe-se que, nos memes, a distância social muitas vezes é obtida pela alta ou baixa
modalização dos enunciados ou pelo uso de pronomes.

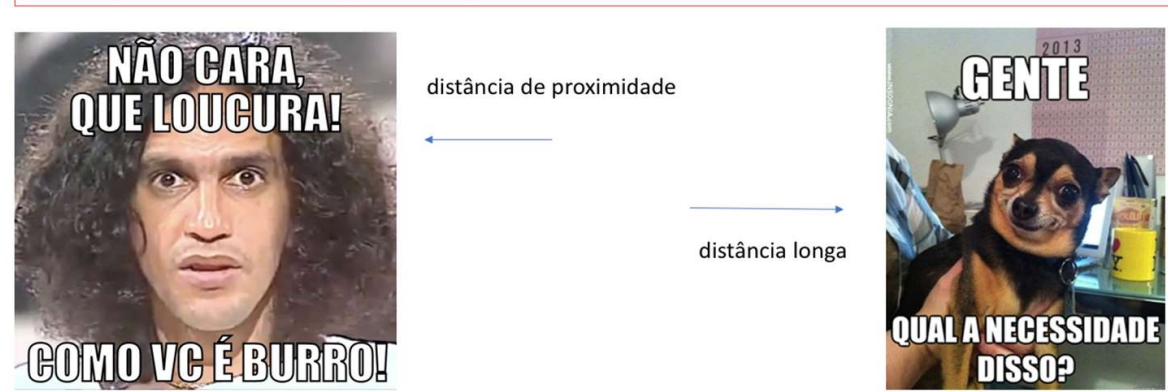

Fonte: Autor

(c) Crítica social e persuasão - construção de persuasão (sedução ou convicção) pela via implícita e com atenção a questões de discriminação, caricaturas ou estereótipos, ou quaisquer outros significados subjacentes ao texto e ofensivos para alguma classe ou pessoa. 
(d) Recursos persuasivos - Emprego de recursos como ironia, humor e metáforas para criticar e posicionar-se ideologicamente, seguindo os preceitos da boa polidez. O professor pesquisador se apresentou e discutiu exemplos de estratégias de convencimento e humor. É importante notar que esta etapa da intervenção pedagógica foi a de maior dificuldade no processo da sequência didática, uma vez que o professor pesquisador conduziu debates entre os alunos para a construção coletiva do que seria, na opinião daquele grupo, adequado ou não ao gênero no que se refere às representações de pessoas e grupos sociais. Notou-se um conflito de interesses entre a liberdade de expressão dos discentes e os valores partilhados pelo grupo, tal que alguns alunos evidenciaram dificuldade em produzir humor senão pela exploração de abjeção. A saída mais encontrada pelos alunos foi pela via da modalização, porém, este módulo da SD foi especialmente produtivo para a identificação e desconstrução coletiva de paradigmas ideológicos apoiados em estereótipos (presentes na produção inicial na ordem de cerca de $70 \%$ ).

Após diversas atividades de análise de textos e ensino do gênero na etapa modular, os alunos realizaram a produção final (doravante PF), na qual aplicaram o que aprenderam para realizar a reescrita individual da primeira atividade. Adiante, apresentamos uma análise da produção final dos alunos.

\section{Análise do Gênero Meme pela Perspectiva da GDV e EPG}

Como tratado anteriormente, para Hasan (1989), o conceito de Estrutura Potencial Genérica (EPG) especifica "que elementos devem ocorrer em cada e toda instância de um discurso particular; e como esses vários elementos se relacionam" (HASAN, 1989, p. 128). "Elemento" é definido como um estágio com alguma consequência para a progressão de um texto, de tal forma que "cada estágio em uma atividade social é um elemento da estrutura dessa atividade" (HASAN, 1989, p. 
142). Sendo assim, passamos a observar os estágios obrigatórios, opcionais e recursivos ou iterativos na produção dos alunos:

\subsection{Estágios obrigatórios}

Nos memes, o uso da imagem, na produção da amostra da pesquisa, foi elemento notadamente obrigatório, no entanto, seu uso não é aleatório, percebemos que seguiu basicamente, quatro padrões:

1) imagem amplamente conhecida, na medida que tem carga semântica de sentido compartilhado e com abrangente de contexto de cultura (exemplos, Figuras 7 e 8).

Figuras 7 e 8 - Produções finais dos Alunos $M$ e 0

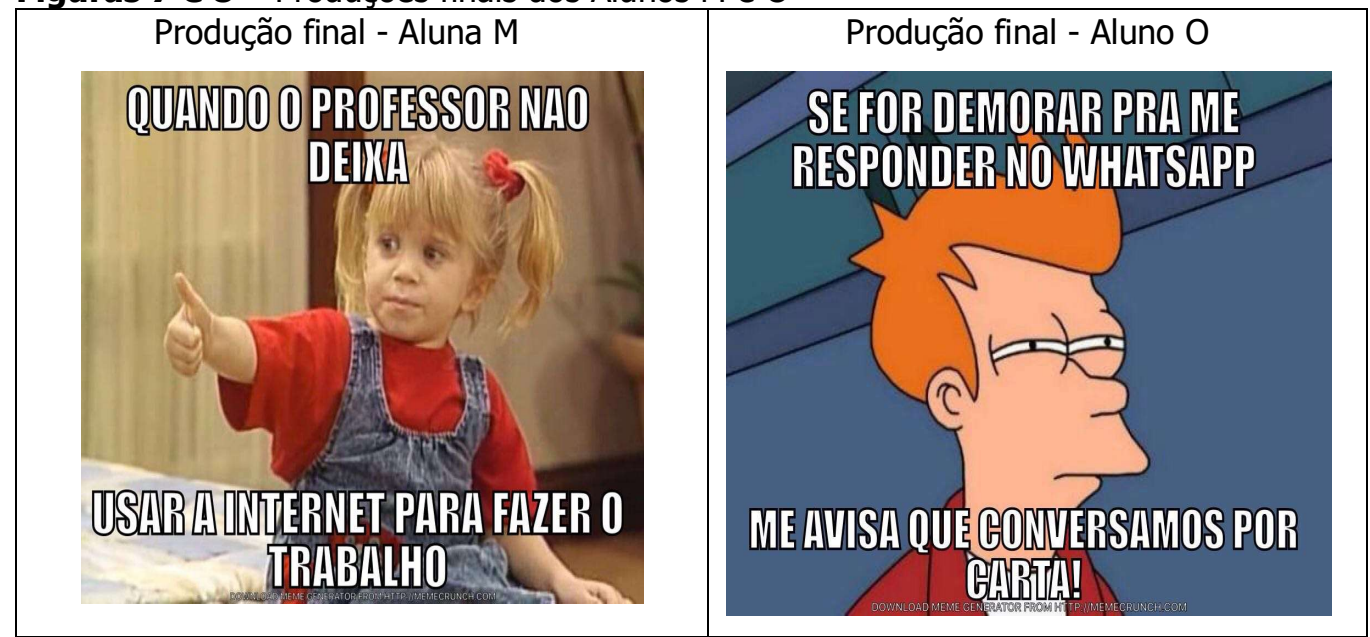

Fonte: Autor

2) imagem conhecida no contexto particular dos interlocutores como, por exemplo, a imagem de um amigo, ou personagens de uma cultura mais restrita (personagens da política brasileira, artistas locais, etc.) (exemplos, Figuras 9 e 10); ou 
Meme: gênero e prática de ensino pela sequência didática

Figuras 9 e 10 - Produções finais dos Alunos $\mathrm{N}$ e L
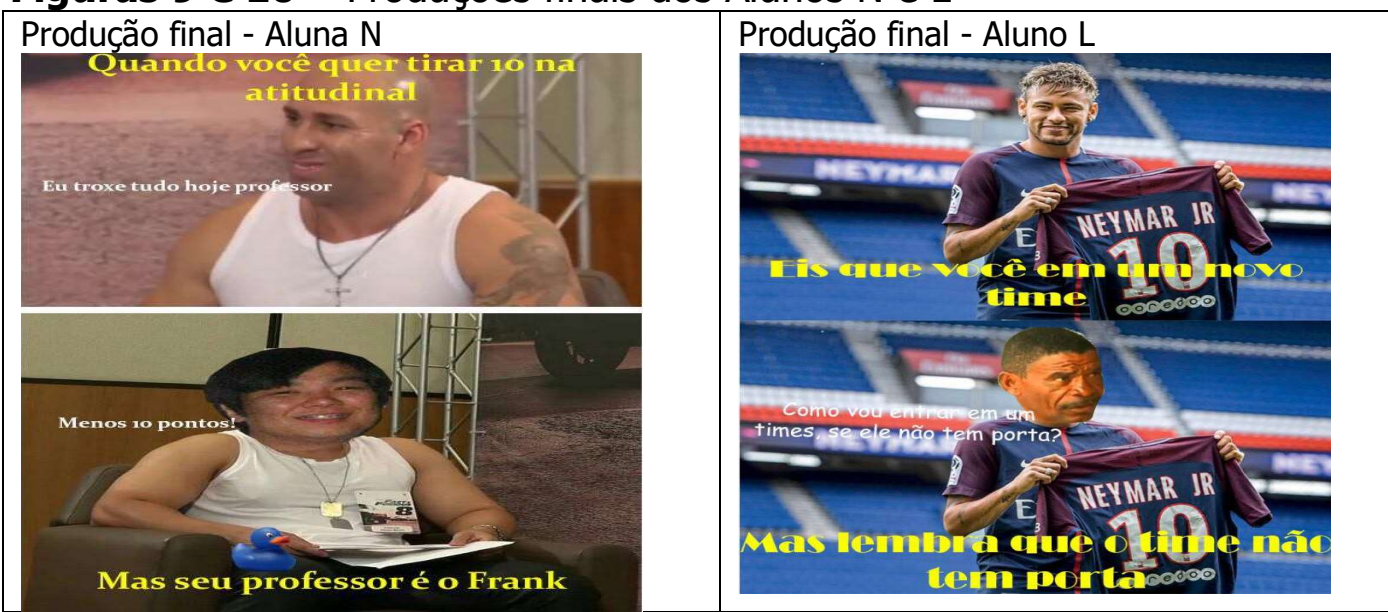

Fonte: Autor

3) imagem caricata que representa realizações concretas de sentidos abstratos como, por exemplo, sarcasmo, ironia, dor, decepção etc., ou ainda reações físicas ou expressões faciais (exemplos, Figuras 11 e 12).

Figuras 11 e 12 - Produções finais dos Alunos J e W

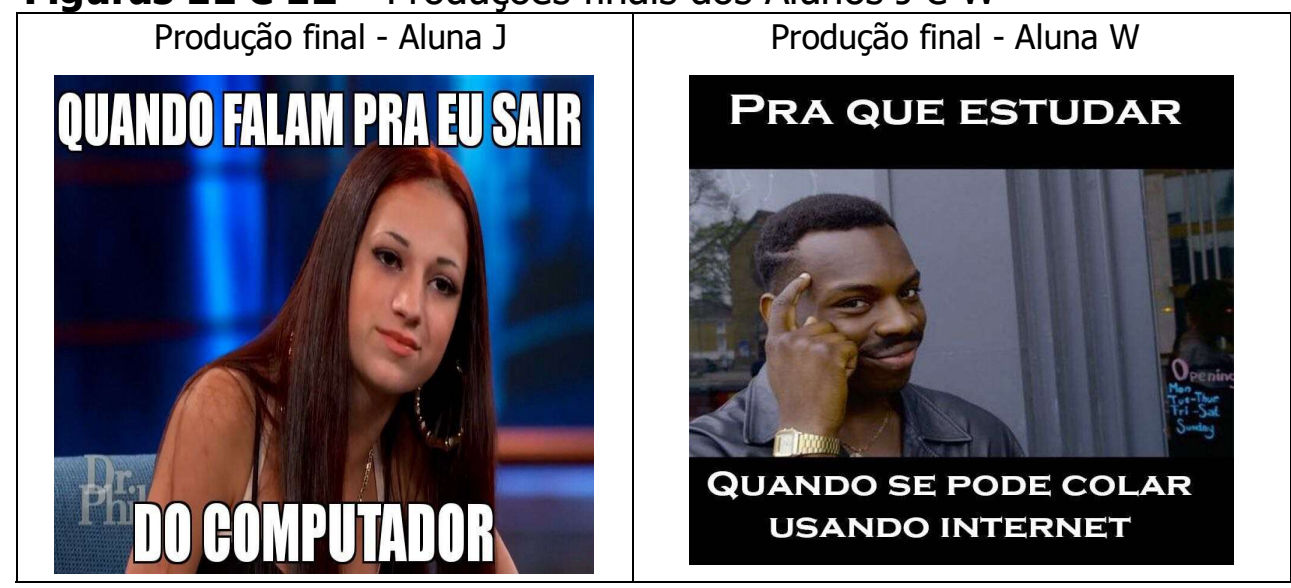

Fonte: Autor

4) duas ou mais imagens que devem ser lidas de forma associada (exemplo, Figura 13). 
Figura 13 - Produção finais da Aluna V (Espanhol)

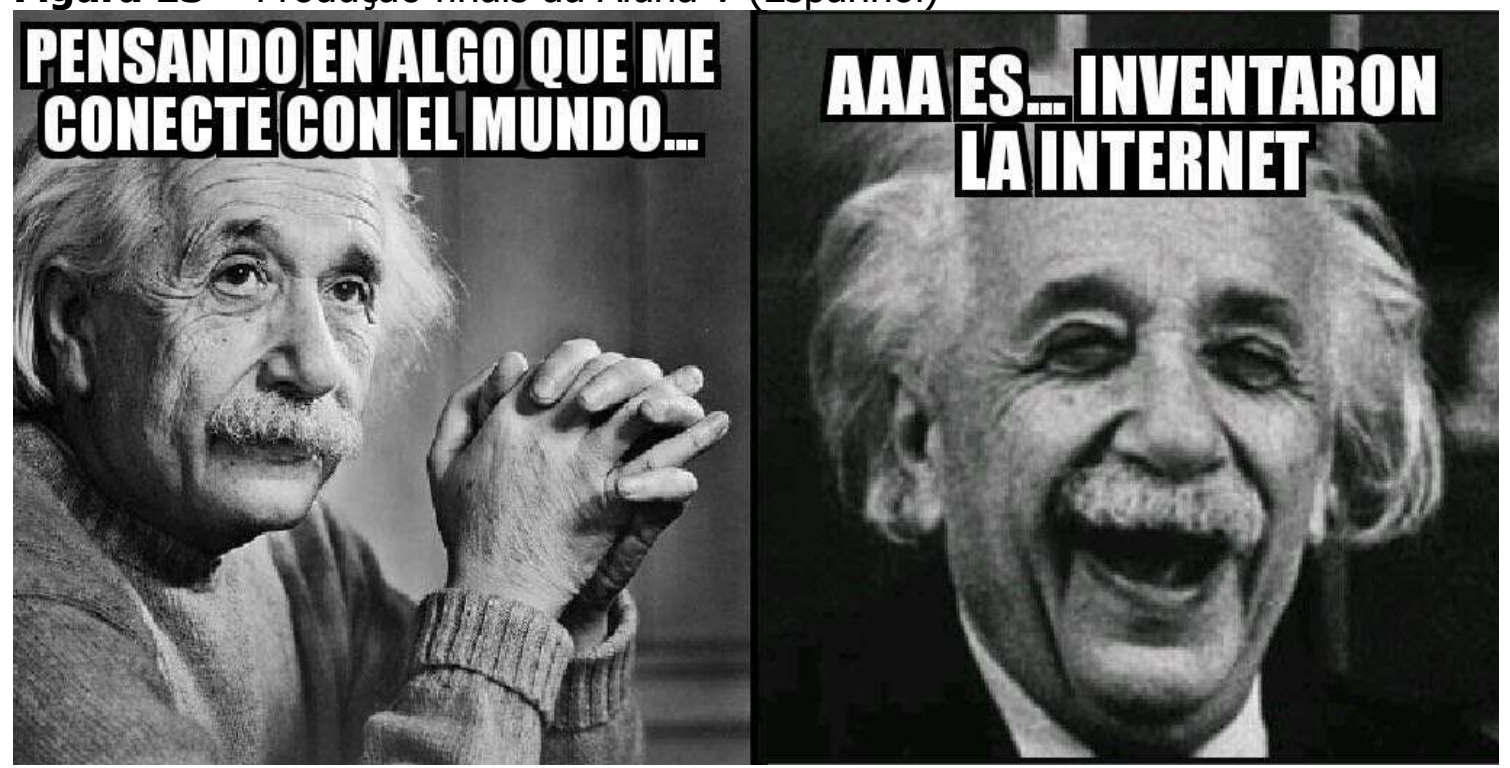

Fonte: Autor

Outro elemento obrigatório nas produções correspondeu ao estilo dos textos escritos, variando entre o informal e o vulgar. Portanto, houve padrão na amostra quanto ao processo de seleção de recursos lexicais e morfossintáticos do enunciado verbal.

Além disso, quanto à integração do texto verbal e não-verbal (cf. GDV), sua mera presença foi elemento obrigatório nas produções, porém, ao contrário do que acontece com a imagem, o texto escrito seguiu padrões de ocorrência que preencheram requisitos opcionais da formação do gênero, como veremos adiante.

\subsection{Estágios opcionais}

No que tange à organização textual do elemento escrito, este seguiu basicamente dois padrões de ocorrência de caráter opcional:

1) elementos textuais escritos e imagéticos nas partes superiores e inferiores nas seguintes ordens de sentido: enunciado verbal (parte superior) $\rightarrow$ enunciado 
imagético (parte inferior) ou enunciado imagético (parte superior) $\rightarrow$ enunciado verbal (parte inferior) (exemplos, Figuras 14 e 15).

Figuras 14 e 15 - Produções finais dos Alunos I e Z

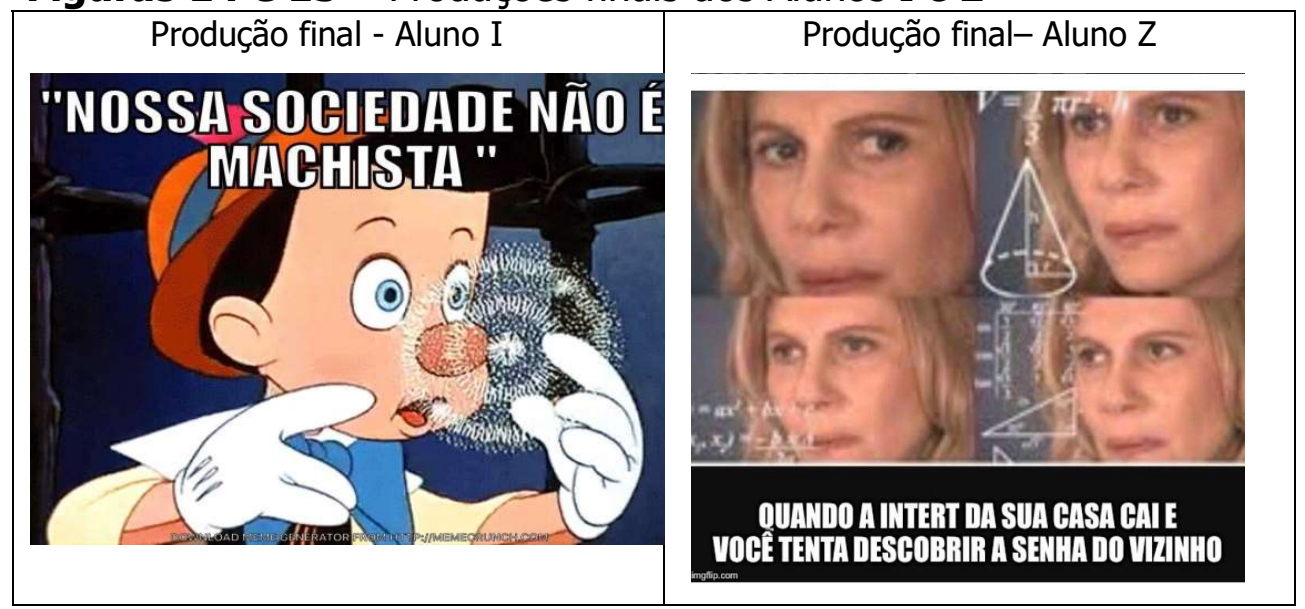

Fonte: Autor

2) elemento textual escrito na parte superior e inferior da imagem, de modo que o efeito completo de sentido (enunciado) seja dependente da seguinte relação: texto escrito (parte superior) $\rightarrow$ texto imagético (central) $\rightarrow$ texto escrito (parte inferior) $=$ enunciado completo (Figuras 16 e 17).

Figuras 16 e 17 - Produções finais dos Alunos W e X

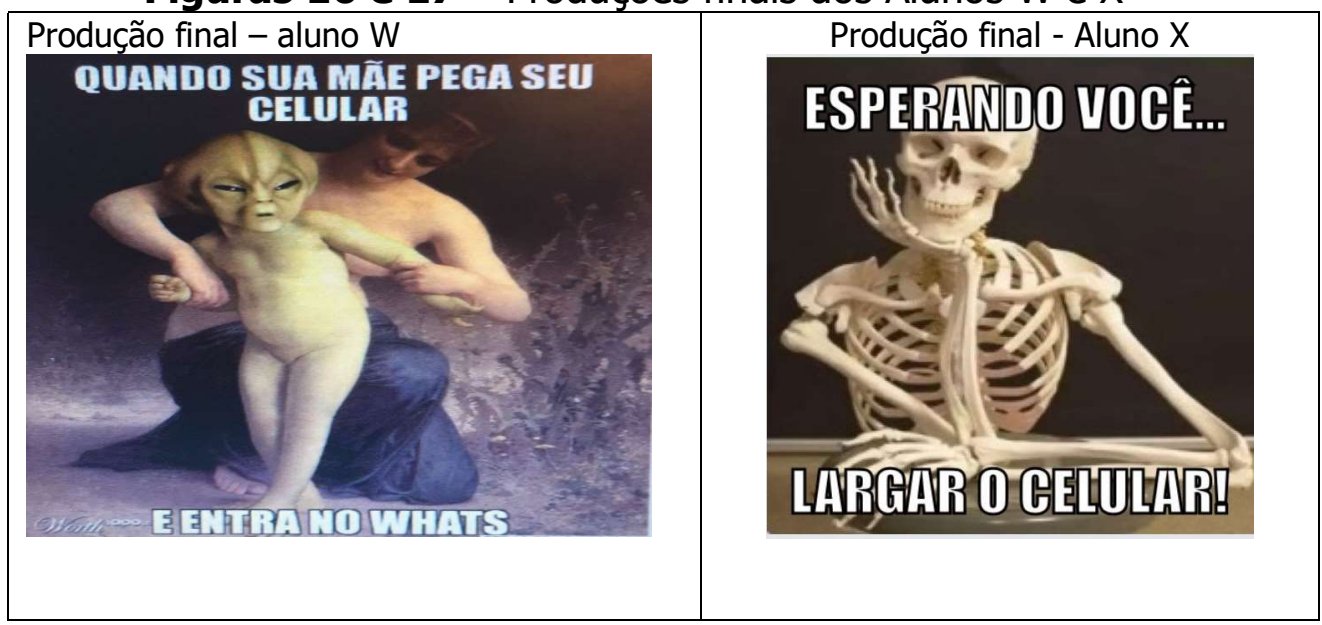

Fonte: Autor 
Ademais, a produção discente apresentou grande profusão de pautas temáticas e formas típicas de tratamento do tema. Tal miríade de assuntos (conteúdo temático) nos indica que os temas ora abordados compõem também característica opcional do gênero.

\subsection{Estágios recursivos ou iterativos}

A organização recursiva ou iterativa dos memes analisados ocorreu, basicamente, de três maneiras distintas:

1) texto escrito Marginal e texto imagético Saliência (cf. GDV), geralmente criando efeito de humor (exemplos, Figuras 18 e 19).

Figuras 18 e 19 - Produções finais dos Alunos $\mathrm{H} \mathrm{e} \mathrm{X}$

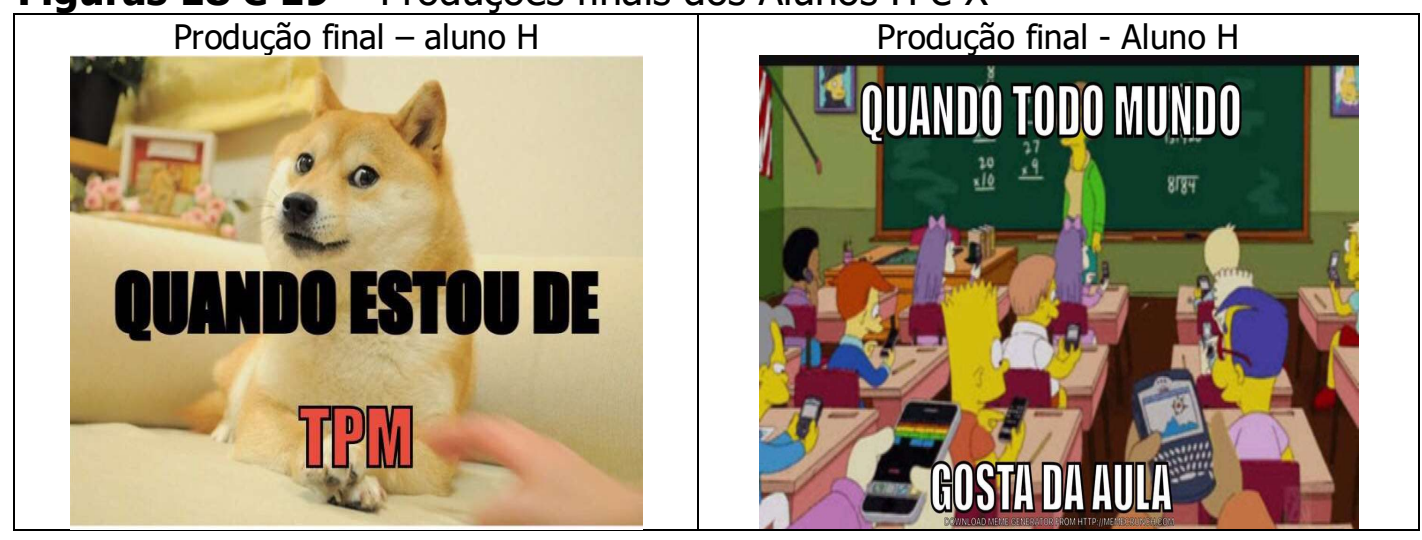

Fonte: Autor

2) texto imagético Marginal e texto escrito Saliência (cf. GDV), geralmente criando efeito de humor (exemplos, Figuras 20 e 21). 
Figuras 20 e $\mathbf{2 1}$ - Produções finais dos Alunos W e X

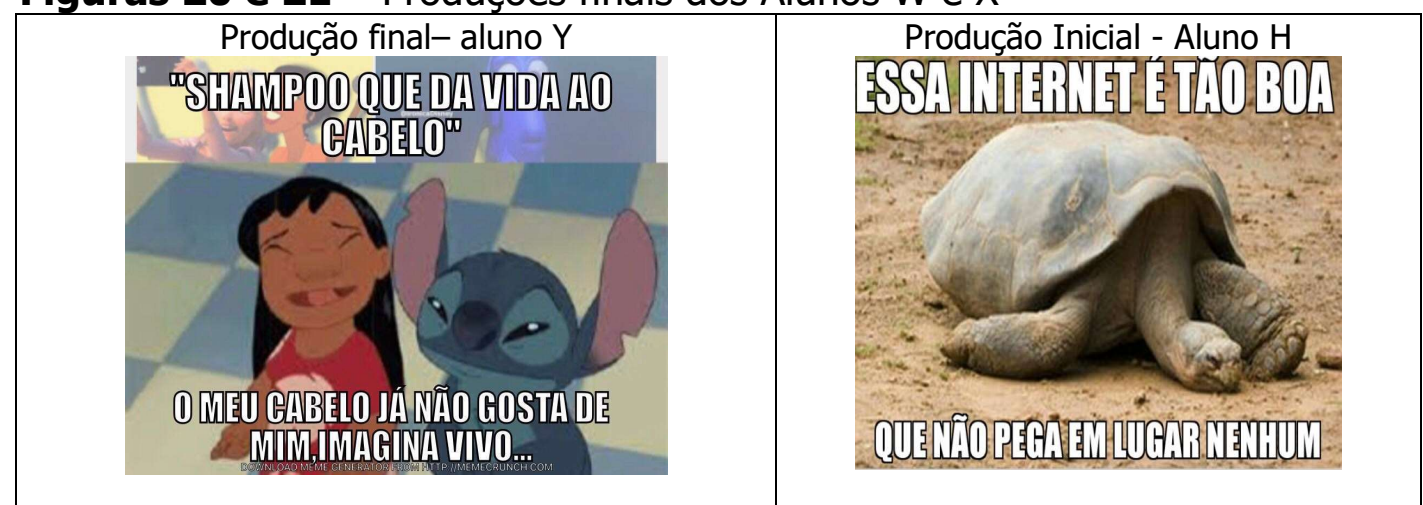

Fonte: Autor

3) o texto escrito e o texto visual têm relação de interdependência específica para criar o efeito de sentido esperado pelo autor, geralmente criando efeito de humor ou ironia (exemplos, Figuras 22 e 23).

Figuras 22 e 23 - Produções finais dos Alunos $M$ e $P$

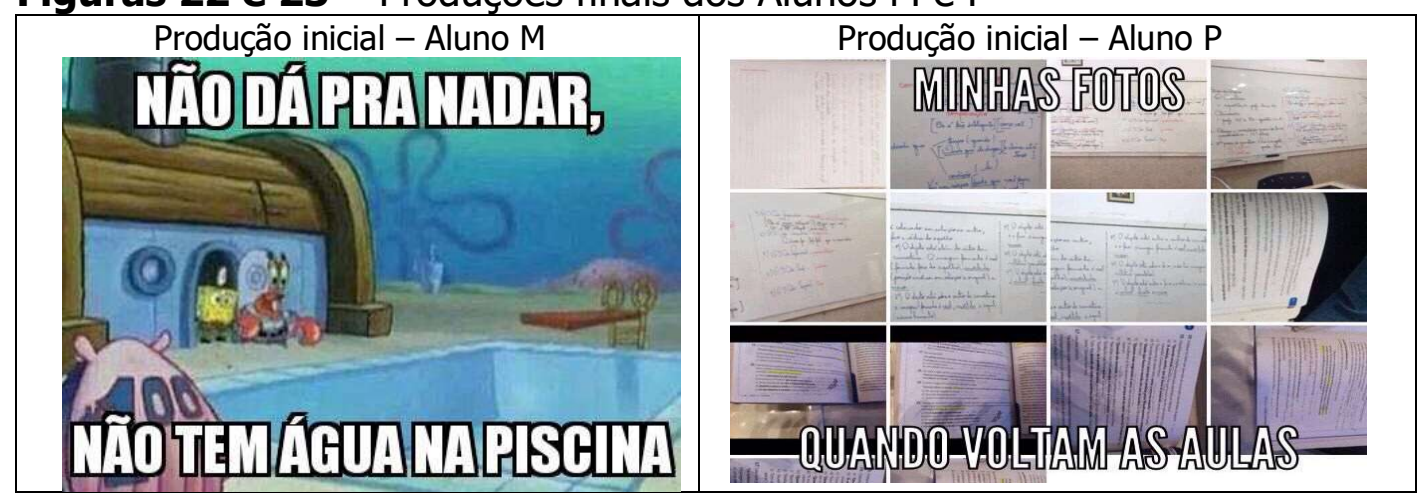

Fonte: Autor

\section{Considerações Finais}

Baseamos nossa pesquisa na importância de discutir propostas de ensino do gênero meme. A utilização da Sequência Didática, como metodologia de ensino interventiva, foi exitosa, uma vez que partimos dos conhecimentos prévios dos alunos para fundamentar com criticidade o planejamento da intervenção didática. Portanto, a SD mostrou ser um modelo adequado para o planejamento de aulas de 
ensino de gênero. As reflexões, inferências, críticas e exposições de opiniões que essa estratégia didático-pedagógica possibilita, estimulam o aluno, pois ele se vê como participante ativo do processo de ensino-aprendizagem, não só no desenvolvimento de conceitos e teorias escolarizados, mas também na maior propriedade e consciência no exercício da cidadania e na atuação relevante em suas esferas de convívio.

Ao final da intervenção pedagógica, houve proeminente melhoria no texto do alunado no que se refere às competências de leitura e de escrita, com destaque à comparação e percepção de semelhanças e diferenças entre diversos gêneros textuais ou discursivos; o reconhecimento e emprego de propriedades de textos multimodais; e a utilização de recursos léxico-gramaticais diversos para posicionamento crítico.

Os fundamentados teórico-metodológicos da Estrutura Potencial Genérica e da Gramática do Design Visual foram utilizados como alicerce da pesquisa. Por meio das análises, foi possível delinear que a produção inicial diagnosticou muitos problemas, como a exposição de ideias preconceituosas, disseminação do ódio, pouca ou nenhuma preocupação com a relação entre o elemento visual e o verbal, desconhecimento dos recursos persuasivos, confusão sobre a estrutura do gênero textos análogos ao da tirinha humorística, dificuldades na inferência das mensagens implícitas. No entanto, os bons resultados da produção final foram promissores no sentido de evidenciar a importância de se trabalhar o texto multimodal em gêneros emergentes que privilegiem a formação da opinião em sala de aula, explorando sua estrutura e finalidade discursiva.

\section{Referências}

BLACKMORE, Susan. The meme machine. Oxford: Oxford Paperbacks, 2000.

BRASIL. Ministério da Educação. Parâmetros curriculares nacionais: ensino fundamental. Brasília: MEC, 1998. 
Meme: gênero e prática de ensino pela sequência didática

BROWN, Penelope; LEVINSON, Stephen C.; LEVINSON, Stephen C. Politeness: some universals in language usage. Cambridge: Cambridge University Press, 1987.

CERVETTI, Gina; PARDALES, Michael J.; DAMICO, James S. A tale of differences: comparing the traditions, perspectives, and educational goals of critical reading and critical literacy. Reading online, n. 9, 2001. Disponível em: http:/ /www.readingonline. org/articles/cervetti/. Acesso em: 27 jan. 2004.

CORACINI, Maria José Rodrigues Faria. CORACINI, M. J. (org.). O jogo discursivo na aula de leitura: língua materna e língua estrangeira. Campinas: Pontes, 1995.

COSCARELLI, Carla Viana; RIBEIRO, Ana Elisa (org.). Letramento digital: aspectos sociais e possibilidades pedagógicas. 2. ed. Belo Horizonte: Autêntica, 2007.

COSTA VAL, Maria da Graça. Atividades de produção de textos escritos em livros didáticos de $5 a$ a 8 a séries do ensino fundamental. In: ROJO, Roxane; BATISTA, Antônio Augusto Gomes. Livro didático de língua portuguesa: letramento e cultura escrita. Campinas: Mercado de Letras, 2003. p. 125-152.

DAVISON, Patrick. The language of internet memes. In: MANDIBERG, Michael. The social media reader. New York: New York University Press, 2012. p. 120-134.

DAWKINS, Richard. Memes: the new replicators. In: DAWKINS, Richard. The selfish gene. London: Cambridge, 1976. p. 189-201.

DOLZ, Joaquim; NOVERRAZ, Michele; SCHNEUWLY, Bernard. Sequências didáticas para o oral e a escrita: apresentação de um procedimento. In: SCHNEUWLY, Bernard; DOLZ, Joaquim (org.). Gêneros orais e escritos na escola. Campinas: Mercado de Letras, 2004. p. 95-128.

DONDIS, Donis A.; CAMARGO, Jefferson Luiz. Sintaxe da linguagem visual. São Paulo: Martins Fontes, 1997.

EGGINS, Sírio; MARTIN, James R. Genres and registers of discourse. London: Routledge, 1997.

GARCIA, Liliana Bueno dos Reis. A ideologia e o poder disciplinar como formas de dominação. Trans/Form/Ação, São Paulo, n. 11, p. 53-59, 1988.

GOFFMAN, Erving. Frame analysis. New York: Harper Colophon books, 1976.

GOFFMAN, Erving. On face-work: an analysis of ritual elements in social interaction. Psychiatry: journal for the study of interpersonal processes. London, $v$. 18, n. 3, p. 213-231, 1967. 
Meme: gênero e prática de ensino pela sequência didática

HALLIDAY, Michael Alexander Kirkwood. An introduction to functional grammar. 2. ed. London: Edward Arnold, 1994.

HALLIDAY, Michael Alexander Kirkwood; HASAN, Ruqaiya. Language, context, and text: aspects of language in a social-semiotic perspective. Victoria: Deakin University, 1989. p. 52-69.

KARWOSKI, Acir Mário; GAYDECZKA, Beatriz. Multiletramentos na escola. Revista Brasileira de Educação, Rio de Janeiro, v. 18, n. 55, p. 1053-1056, 2013.

KRESS, Gunther R.; VAN LEEUWEN, Theo. Multimodal discourse: the modes and media of contemporary communication. London: Oxford University Press, 2001.

KRESS, Gunther R.; VAN LEEUWEN, Theo. Reading images. the grammar of visual design. Kingdom: Psychology Press, 1996.

MACIEL, Ruberval Franco; TAKAKI, Nara Hiroko. Novos letramentos pelos memes: muito além do ensino de línguas. In: MACIEL, Ruberval Franco; JESUS, Dánie Marcelo de (org.). Olhares sobre tecnologias digitais. linguagens, ensino, formação e prática docente. Campinas: Pontes, 2015. p. 53-82.

MAGNANI, Luiz Henrique. Um passo para fora da sala de aula: novos letramentos, mídias e tecnologias. Revista X, Curitiba, v. 1, p. 1-18, n. 1, 2011.

MARTIN, James R. Beyond exchange: appraisal system in english. In: HUNSTON, Susan; THOMPSON, Geof. (ed.). Evaluation in text. authorial stance and the construction of discourse. Oxford: Oxford University Press, 2000. p. 145-172.

MASSARUTO, Filippo Antonio; DO VALE, Lara Ferreira; ALAIMO, Marcela Miquelon. Educomunicação: o meme enquanto gênero textual a ser utilizado na sala de aula. Revista Pandora Brasil, São Paulo, v. 13, n. 83, p. 1-11, jun. 2017.

MATTOS, Andréa Machado de Almeida; VALÉRIO, Kátia Modesto. Letramento crítico e ensino comunicativo: lacunas e interseções. Revista Brasileira de Linguística Aplicada, Belo Horizonte, v. 10, n. 1, p. 135-158, 2010.

MENDONÇA, Marina Célia; LARA, Marina Totina de Almeida. Gêneros do discurso, ensino/aprendizagem e verbo-visualidade: o caso do meme em um curso prévestibular online. Prolíngua, João Pessoa, v. 12, n. 2, 149-162, out./dez. 2017.

MINAYO, Maria Cecília de Souza. Pesquisa social: teoria, método e criatividade. São Paulo: Editora Vozes Limitada, 2011. 
OLIVEIRA, Marcos Antônio; MALTA, Daniela Paula Lima Nunes; AQUINO, Alisson Arlindo Silva. Práticas de letramento e multimodalidade: uma análise sobre o uso do gênero "meme" na sala de aula. Revista do GELNE, Natal, v. 19, n. 2, p. 62-77, 2017.

POSSENTI, Sírio. Os humores da língua. Campinas: Mercado de Letras, 1998.

ROJO, Roxane; MOURA, Eduardo. Multileramentos na escola. São Paulo: Parábola Editorial, 2012. 